\title{
Beam-to-Column Connections with Demountable Energy Dissipative Plates
}

\author{
Vasile-Mircea Venghiac*, Mihail Staşcov and Mihai Budescu \\ Faculty of Civil Engineering and Building Services, Gheorghe Asachi Technical University of laşi, Iaşi, Romania
}

The behavior of steel structures subjected to seismic actions depends directly on the connections behavior. There are two current tendencies for ensuring the structural ductility: allowing the formation of plastic hinges in the beams by using reduced beam sections or reduced web sections or by ensuring the plastic hinge formation in the connection by using dissipative elements. This paper presents a new perspective regarding the energy dissipation mechanism formation within the beam-to-column connection. The design of connections capable of dissipating large amounts of energy, with an acceptable strength and ductile behavior is a real challenge for engineers. Sustainability is a big advantage

OPEN ACCESS

Edited by:

Panagiotis Mergos,

City University of London,

United Kingdom

Reviewed by:

Chrysanthos Maraveas, University of Liège, Belgium

Emanuele Brunesi,

European Centre for Training and

Research in Earthquake

Engineering, Italy

*Correspondence:

Vasile-Mircea Venghiac mircea.venghiac@tuiasi.ro

Specialty section:

This article was submitted to

Earthquake Engineering,

a section of the journal

Frontiers in Built Environment

Received: 06 December 2017

Accepted: 22 February 2018

Published: 07 March 2018

Citation:

Venghiac V-M, Staşcov $M$ and Budescu M (2018) Beam-to-Column

Connections with Demountable

Energy Dissipative Plates.

Front. Built Environ. 4:15. doi: 10.3389/fbuil.2018.00015 for these connections. Another big advantage is the possibility of restoring the functionality of the damaged construction in a short time interval and with reduced costs. The introduction of connections with demountable energy dissipative plates can be a step forward in designing new beam-to-column connections for steel structures.

Keywords: non-linear analysis, Eurocode 3, energy dissipative connections, ductile design, plastic hinges

\section{INTRODUCTION}

Steel structures are frequently used in seismic areas due to their ductile behavior, high energy dissipation capacity and relatively fast and simple construction. The degradations of structures after the 1994 Northridge and 1995 Kobe earthquakes showed that classic beam-column connections have a brittle behavior. Most connections failed due to stress concentrations in the welds, material imperfections, or weld defects. The classic design of steel structures proved to be inefficient. Thus, the ductile failure requirement was introduced by ensuring the development of a plastic hinge at the ends of the beams and at the base of the columns, and at the ground floor of the construction (Engelhardt and Husain, 1993).

Prior to the Northridge and Kobe earthquakes, the connections were considered as either fully rigid or pinned. In the 1990s, it was proved that the majority of the connections designed as fully rigid had in fact a semi-rigid behavior. The same thing was observed for pinned connections.

According to Eurocode 3 part 1-8 (CEN EN., 2005), a moment resistant connection needs to have three essential characteristics: stiffness $\left(S_{j, \text { ini }}\right)$, bending moment resistance $\left(M_{j, \mathrm{Rd}}\right)$ and plastic deformation capacity, ductility, or rotation capacity $\left(\Phi_{u}\right)$.

According to the stiffness values, connections can be classified as pinned, fully rigid, or semirigid. Pinned connections should transmit the internal forces without developing significant bending moments which could affect the connected structural elements. A fully rigid connection presents a high rotational stiffness and semi-rigid connections do not satisfy the criteria for fully rigid or pinned connections.

According to the bending moment resistance, connections can be classified as pinned, full strength, or partial strength. A full strength connection develops a larger capable bending moment 
than the plastic capable bending moments of the connected elements. Thus, yielding will appear in the weakest structural member connected in the joint.

Considering the classifications presented above, a general classification can be made taking into consideration both aspects, as follows:

- full strength and rigid connections,

- full strength and semi-rigid connections,

- partial strength and rigid connections,

- partial strength and semi-rigid connections,

- pinned and semi-rigid connections,

- pinned connections.

Knowing the behavior of a connection is important because the order of plastic hinge formation in the structure and the collapse mechanism can be evaluated.

Generally, full strength beam-to-column connections are designed to ensure the plastic hinge formation in the connection or in the beam, thus avoiding plastic deformations of the columns. This requirement is fulfilled by varying the connection components characteristics. Although there are many technical solutions for moment resistant connections, the most frequently used type is the end plate connection with bolts or welding the beam directly to the column. Both of the connected structural elements have I or $\mathrm{H}$ sections. All components of this connection can influence the behavior: the end plate type (exact, extended, or extended with stiffeners), end plate thickness (Venghiac et al., 2017), bolt diameter, the compression or tension stiffeners on the web panel of the column, and the shear stiffener on the web panel of the column.

\section{PAST STUDIES REGARDING CLASSIC BEAM-TO-COLUMN CONNECTIONS}

Many experimental and numerical studies on classic welded or bolted connections showed their vulnerability which manifested in a brittle failure with limited or no ductility. The T-stub connections studied by Swanson and Leon failed with net section fractures of the stem or in a tension bolt fracture mode which were the most sudden and brittle failure modes observed for these connections (Swanson and Leon, 2000). Another example is the prefabricated steel beam-to-column connection studied by $\mathrm{Hu}$ et al. (2014) which also showed limited energy dissipation and brittle failure. Other studies improved upon the procedures used in finite element analyses by using a SHELL bolt model instead of a realistic 3D bolt model (Moshaly et al., 2011), or by incorporating different algorithms for contacts, non-linear shear links in the analysis (Diaz et al., 2011; Brunesi et al., 2014).

Therefore, different typologies were used to move the formation of the plastic hinge from the connection to the beam. This can be achieved by adding haunches or horizontal splices on top of the beam flanges and welded on site. Another solution of concentrating the plastic deformations in the beam can be achieved by reducing the beam sections. This can be done by cutting a part of the beam flanges: reduced beam section (RBS) or by cutting holes in the web of the beam: reduced web section (RWS).

The research carried out by Tsavdaridis on connections with RBS or RWS beams confirmed a good behavior from the point of view of stress distribution under cyclic loading (Tsavdaridis and Papadopoulos, 2016; Naughton et al., 2017). An important criterion is for the connection to have sufficient strength and stiffness in order to transmit the yielding stresses in the weakened section of the beam, far away from the connection in order to ensure the "weak beam-strong column" mechanism which means to ensure the formation of the plastic hinge in the beam. Another important goal of the RBS geometry was to protect the steel connection (endplate, bolts, welds, column flange) from plastification (Sofias et al., 2014).

All this research showed that RBS and RWS are a good solution for ensuring ductility of steel structures, although there are situations where the plastic hinge formation is preferred in the connection. The connections consist of plates especially designed to yield under loading and dissipate the seismic energy. Some examples include: the PI damper connection (Koetaka et al., 2005), the slit damper connection (Chan and Albermani, 2008; Oh et al., 2009; Saffari et al., 2013), double split tee (DST) connections (Herrera et al., 2013; Bravo and Herrera, 2014; Latour and Rizzano, 2015; Tong et al., 2016), dissipative splice connections (Calado et al., 2013; Valente et al., 2017a,b), or connections with memory shape alloy bolts (Wang et al., 2015; Yam et al., 2015).

\section{PROPOSED BEAM-TO-COLUMN CONNECTIONS WITH ENERGY DISSIPATIVE PLATES}

Ensuring the formation of the plastic hinge in the connection presents a series of advantages. The most significant are the possibility of restoring the function of the damaged building in a short time with low repair difficulty and costs, the possibility of designing the connection to fulfill any strength and stiffness requirements. Also, the plastic hinge formation in the beam or in the end-plate connection leads to difficult and costly repairs of the damaged components: beam ends and end plates.

For this reason, we believe that greater attention should be paid to these types of connections. A series of beam-to-column connections with demountable dissipative plates is being studied at the Department of Structural Mechanics of the Faculty of Civil Engineering of Iaşi. Part of these connections were inspired by the TADAS and ADAS dampers (Tsai et al., 1993) by adopting such dissipative plate shapes. Several versions were considered, including rectangular straight or bent plates (Figure 1) which presented a good energy dissipation capacity. The beam of this connection rests on a cantilever of the column by the means of a circular bar welded on the bottom flange of the beam. The top flange is connected to one end of a dissipative plate which on the other end is attached to the column flange. The circular bar allows the rotation of the beam on the column cantilever. Under seismic actions, the rotation of the beam will act upon the dissipative plate which starts to yield resulting in the seismic energy dissipation.

\section{FINITE ELEMENT MODEL}

In order to analyze one of these connections under cyclic loading, a finite element model was developed using the ANSYS finite 

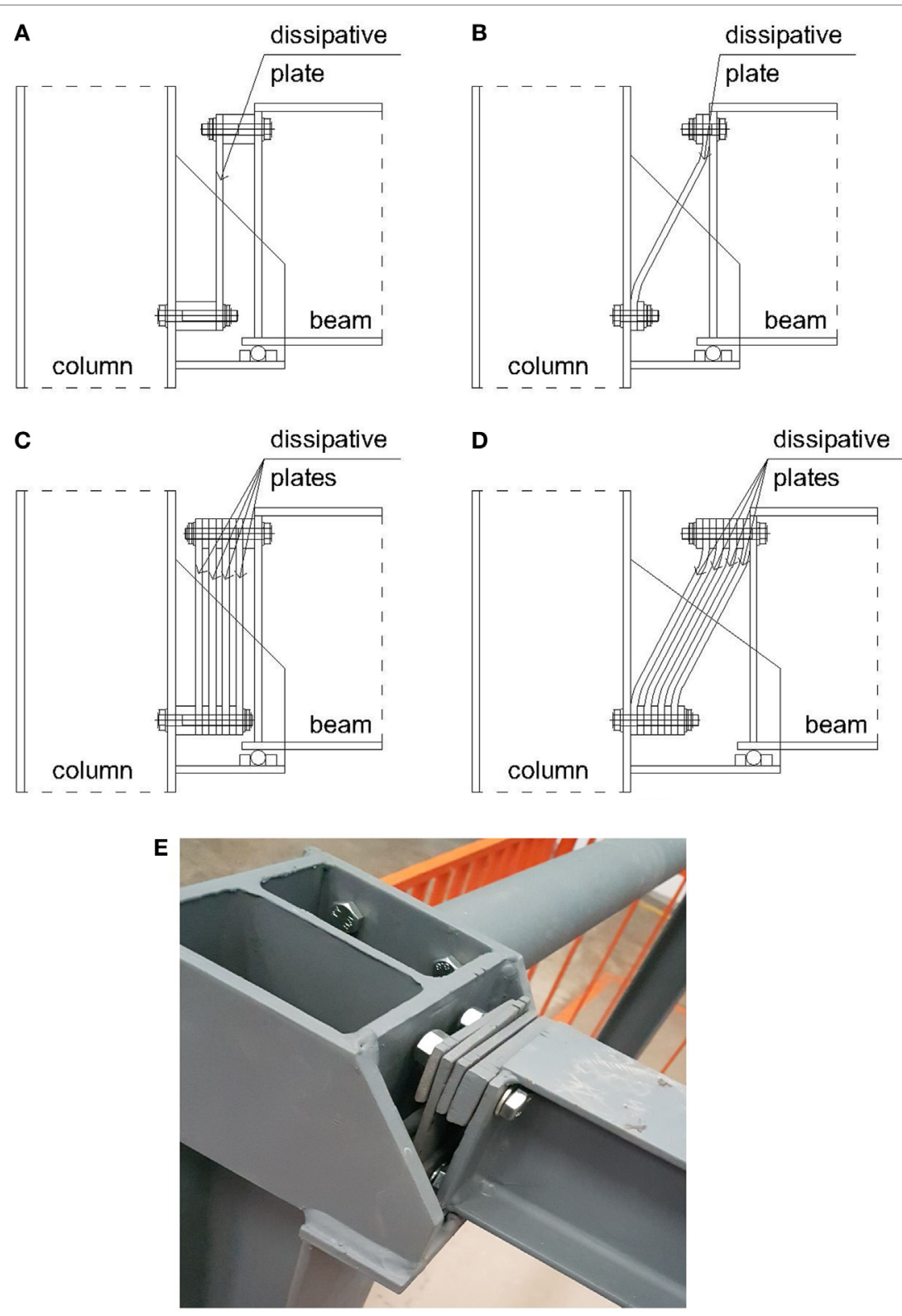

FIGURE 1 | Beam-to-column connections with different versions of dissipative plates: (A) one straight plate, (B) one bent plate, (C) multiple straight plates, (D) multiple bent plates, and (E) one straight plate-experimental model.

element modeling software. The model consists of one rectangular dissipative plate bolted at the top to the end of the beam and at the bottom to the column flange. In order to simplify the model, only the dissipative plate, the bolts, and a small section of the column flange are taken into consideration. The deformations of the column and beam are neglected. The dimensions of the plate are $290 \mathrm{~mm} \times 170 \mathrm{~mm} \times 15 \mathrm{~mm}$. The steel grade is S235 and the bolts are 10.9 property grade. The column flange section is defined as a fixed support and the load is applied on the top bolts. The loading protocol is consistent with AISC (ANSI/AISC $341,2016)$ with an addition of two extra cycles at $\theta=0.05 \mathrm{rad}$. The local displacement values on the top bolts of the dissipative plate were geometrically determined from $\theta$. The behavior of the connection under cyclic load is presented in Figure 2. The displacement $(\Delta)$ applied at the top of the dissipative plate is plotted on the horizontal axis and the force reaction $(\mathrm{F})$ on the vertical axis. The force reaction is obtained with the probe tool where the displacement was applied. The hysteretic response shows a satisfactory ductile behavior. However, these results need to be validated by experimental tests.

This connection can be designed with more plates resulting in higher connection stiffness, bending moment resistance, and energy dissipation. After a major earthquake, the damaged dissipative plates can be easily replaced by removing the bolts. Also, no temporary support for the beam is necessary during this operation. The dissipative plates can be arranged in other 
A
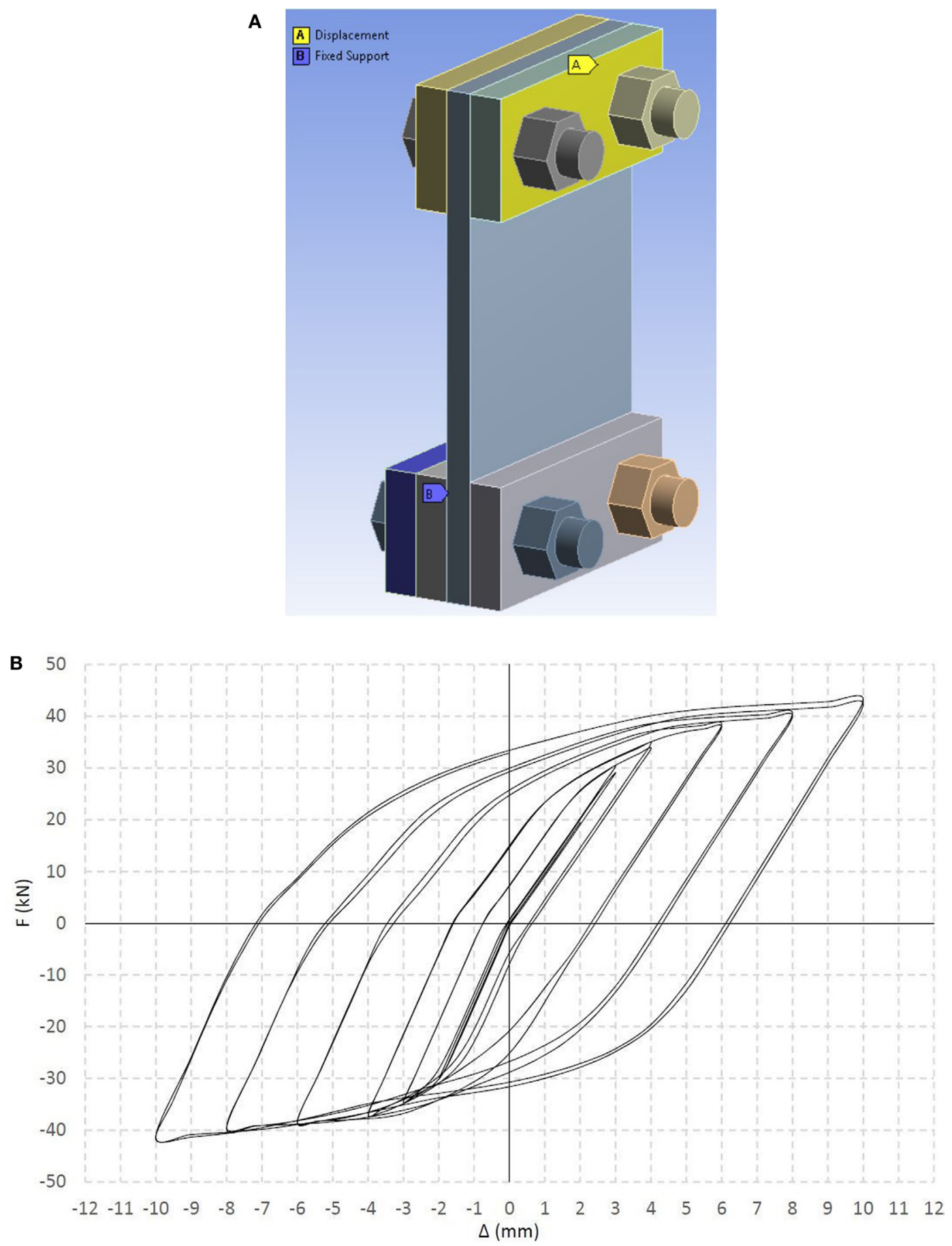

FIGURE 2 | Finite element model of beam-to-column connection with one straight dissipative plate: (A) geometry of finite element in ANSYS and (B) force-displacement curves.

positions and can be designed to have different shapes and sizes in order to increase the efficiency of the connection. Therefore, different categories of connections can be designed from the strength and stiffness point of view.

Other types of connections studied in our Faculty are provided with special devices for taking over the shear forces which appear in the joint. The components and behavior under cyclic loading will be presented in future papers since this connection is the object of a patent which is in the application stage.

Future research should be concentrated on the determination of the behavior of these connections under cyclic actions and of the response (in terms of story drift, overall strength capacity) of different steel frame structures provided with this 
type of connections. We consider that these connections are a step forward in designing beam-to-column connections with demountable energy dissipative plates for steel structures.

\section{REFERENCES}

ANSI/AISC 341. (2016). Seismic Provisions for Structural Steel Buildings. Chicago, IL: American Institute of Steel Construction.

Bravo, M., and Herrera, R. (2014). Performance under cyclic load of built-up T-stubs for double T moment connections. J. Constr. Steel Res. 103, 117-130. doi:10.1016/j.jcsr.2014.08.005

Brunesi, E., Nascimbene, R., and Rassati, G. A. (2014). Response of partiallyrestrained bolted beam-to-column connections under cyclic loads. J. Constr. Steel Res. 97, 24-38. doi:10.1016/j.jcsr.2014.01.014

Calado, L., Proença, J., Espinha, M., and Castiglioni, C. (2013). Hysteretic behaviour of dissipative bolted fuses for earthquake resistant steel frames. J. Constr. Steel Res. 85, 151-162. doi:10.1016/j.jcsr.2013.02.016

CEN EN. (2005). 1993-1-8 Eurocode 3: Design of Steel Structures - Part 1-8: Design of Joints. Brussels: European Committee for Standardization.

Chan, R. W. K., and Albermani, F. (2008). Experimental study of steel slit damper for passive energy dissipation. Eng. Struct. 30, 1058-1066. doi:10.1016/j. engstruct.2007.07.005

Diaz, C., Victoria, M., Marti, P., and Querin, O. M. (2011). FE model of beamto-column extended end-plate joints. J. Constr. Steel Res. 67, 1578-1590. doi:10.1016/j.jcsr.2011.04.002

Engelhardt, M. D., and Husain, A. S. (1993). Cyclic-loading performance of welded flange-bolted web connections. J. Struct. Eng. 119, 3537-3550. doi:10.1061/ (ASCE)0733-9445(1993)119:12(3537)

Herrera, R., Bravo, M., Gómez, G., and Aedo, G. (2013). Performance of built-up T-stubs for double T moment connections. J. Constr. Steel Res. 88, 289-295. doi:10.1016/j.jcsr.2013.05.022

Hu, F., Shi, G., Bai, Y., and Shi, Y. (2014). Seismic performance of prefabricated steel beam-to-column connections. J. Constr. Steel Res. 102, 204-216. doi:10.1016/ j.jcsr.2014.07.012

Koetaka, Y., Chusilp, P., Zhang, Z., Ando, M., Suita, K., Inoue, K., et al. (2005). Mechanical property of beam-to-column moment connection with hysteretic dampers for column weak axis. Eng. Struct. 27, 109-117. doi:10.1016/j. engstruct.2004.09.002

Latour, M., and Rizzano, G. (2015). Design of X-shaped double split tee joints accounting for moment-shear interaction. J. Constr. Steel Res. 104, 115-126. doi:10.1016/j.jcsr.2014.10.015

Moshaly, E., El-Heweity, M., Abou-Elfath, H., and Osman, M. (2011). Finite element analysis of beam-to-column joints in steel frames under cyclic loading. Alexandria Eng. J. 50, 91-104. doi:10.1016/j.aej.2011.01.012

Naughton, D. T., Tsavdaridis, K. D., Maraveas, C., and Nicolaou, A. (2017). Pushover analysis of steel seismic resistant frames with reduced web section and reduced beam section connections. Front. Built Environ. 3:59. doi:10.3389/ fbuil.2017.00059

Oh, S. H., Kim, Y. J., and Ryu, H. S. (2009). Seismic performance of steel structure with slit dampers. Eng. Struct. 31, 1997-2008. doi:10.1016/j.engstruct.2009. 03.003

\section{AUTHOR CONTRIBUTIONS}

\author{
All authors collaborated equally on the paper.
}

Saffari, H., Hedayat, A. A., and Poorsadeghi Nejad, M. (2013). Post-Northridge connections with slit dampers to enhance strength and ductility. J. Constr. Steel Res. 80, 138-152. doi:10.1016/j.jcsr.2012.09.023

Sofias, C. E., Kalfas, C. N., and Pachoumis, D. T. (2014). Experimental and FEM analysis of reduced beam section moment endplate connections under cyclic loading. Eng. Struct. 59, 320-329. doi:10.1016/j.engstruct.2013.11.010

Swanson, J. A., and Leon, R. T. (2000). Bolted steel connections: tests on T-stub components. J. Struct. Eng. 126, 50-56. doi:10.1061/(ASCE)0733-9445(2000) 126:1(50)

Tong, L., Chen, Y., Chen, Y., and Fang, C. (2016). Cyclic behaviour of beam-tocolumn joints with cast steel connectors. J. Constr. Steel Res. 116, 114-130. doi:10.1016/j.jcsr.2015.09.005

Tsai, K. C., Chen, H. W., Hong, C. P., and Su, Y. F. (1993). Design of steel triangular plate energy absorbers for seismic-resistant construction. J. Earthquake Spectra 9, 505-528. doi:10.1193/1.1585727

Tsavdaridis, K. D., and Papadopoulos, T. (2016). A FE parametric study of RWS beam-to-column bolted connections with cellular beams. J. Constr. Steel Res. 116, 92-113. doi:10.1016/j.jcsr.2015.08.046

Valente, M., Castiglioni, C., and Kanyilmaz, A. (2017a). Numerical investigations of repairable dissipative bolted fuses for earthquake resistant composite steel frames. Eng. Struct. 131, 275-292. doi:10.1016/j.engstruct.2016.11.004

Valente, M., Castiglioni, C., and Kanyilmaz, A. (2017b). Welded fuses for dissipative beam-to-column connections of composite steel frames: numerical analyses. J. Constr. Steel Res. 128, 498-511. doi:10.1016/j.jcsr.2016.09.003

Venghiac, V. M., Staşcov, M., and Budescu, M. (2017). "Analize privind îmbinările grindă-stâlp cu şuruburi," in Proceedings of the 15th National Conference on Steel Structures with International Participation - 15 CONMET (Romanian), 227-234.

Wang, W., Chanc, T. M., and Shao, H. (2015). Seismic performance of beamcolumn joints with SMA tendons strengthened by steel angles. J. Constr. Steel Res. 109, 61-71. doi:10.1016/j.jcsr.2015.02.011

Yam, M. C. H., Fang, C., Lamd, A. C. C., and Zhang, Y. (2015). Numerical study and practical design of beam-to-column connections with shape memory alloys. J. Constr. Steel Res. 104, 177-192. doi:10.1016/j.jcsr.2014.10.017

Conflict of Interest Statement: The authors declare that the research was conducted in the absence of any commercial or financial relationships that could be construed as a potential conflict of interest.

Copyright (c) 2018 Venghiac, Staşcov and Budescu. This is an open-access article distributed under the terms of the Creative Commons Attribution License (CC BY). The use, distribution or reproduction in other forums is permitted, provided the original author(s) and the copyright owner are credited and that the original publication in this journal is cited, in accordance with accepted academic practice. No use, distribution or reproduction is permitted which does not comply with these terms. 